\title{
26. CONSTRAINTS ON THE STATE OF STRESS IN OLD OCEANIC CRUST OF THE INDO-AUSTRALIAN PLATE, NORTHWEST OF AUSTRALIA ${ }^{1}$
}

\author{
David A. Castillo2,3 and Brennan O'Neill 3,4
}

\begin{abstract}
Stress-induced wellbore breakouts have been detected using an ultrasonic borehole televiewer tool (BHTV) run in the basalt section of Hole 765D. A detailed analysis of the breakouts over a depth range of 1125 to $986 \mathrm{mbsf}$ gives a statistically averaged orientation of $121.5^{\circ} \mathrm{N} \pm 9.0^{\circ}$ for the maximum horizontal compressive stress $\left(\mathrm{SH}_{\max }\right)$. Similar $\mathrm{SH}_{\max }$ orientations are observed in industry wells situated on the nearby Australian continental shelf. Using the criteria that wellbore failure occurs when the circumferential compressive stress concentration around the borehole exceeds the compressive strength of the rock, we develop constraints on the stress regime active within the northwest section of the Indo-Australian Plate. The occurrence of these stress-induced breakouts indicates that this region is in a state of compression suitable for supporting reverse and strike-slip faulting. We calculated a stress tensor using the reported $\mathrm{SH}_{\max }$ direction for Site 765 , along with fault-slip data from the $1979 \mathrm{Ms}=5.7$ Broome earthquake located on the western continental shelf. Results indicate a state of compression, while the minimum horizontal compressive stress $\left(\mathrm{Sh}_{\min }\right)$ is approximately equivalent to the vertical overburden (i.e., $S_{2}, S_{3}$, and $S_{\mathrm{v}}$ ). These results are supported by the widespread occurrence of both strike-slip and reverse types of earthquakes in western Australia.
\end{abstract}

\section{INTRODUCTION}

Knowledge of the state of stress is important for understanding plate-driving forces. A wealth of information about the state of stress for continental crust has been collected from a variety of sources (Zoback et al., 1989). The bulk of these data is from compressional axes ( $P$-axis) associated with well-constrained focal mechanism solutions and from in-situ measurements of stress-induced wellbore breakouts. To date, the state of stress in the oceanic lithosphere is largely limited to $P$-axes from oceanic intraplate and interplate earthquakes (Bergman and Solomom, 1985). In-situ stress from wellbore breakouts in deep boreholes within the oceanic crust has been measured near the Mid-Atlantic Ridge in DSDP Hole 395A (Hickman et al., 1984) and in the eastern Pacific in DSDP/ODP Hole 504B (Newmark et al., 1984; Morin et al., 1990). Prior to the drilling of Hole 765D, no in-situ stress measurements had been collected in the Indian Ocean.

The greater Indo-Australian Plate is associated with the highest rate of intraplate deformation. This is particularly true in the Indian Ocean, where the deformation is manifest in the occurrence of widespread intraplate seismicity (Bergman and Solomon, 1985) and by indulations within the basement topography and geoid height (McAdoo and Sandwell, 1985). However, the exact nature and origin of the tectonic stresses responsible for this deformation remain largely unknown. Therefore, one of the objectives for initiating a multiple-leg drilling program in the Indian Ocean (Legs 115 through 123) was to use in-situ methods to understand the nature of this intraplate deformation better. This study presents data about stress orientations from in-situ measurements collected in 140-Ma-old crust at depths of 6700 to $8650 \mathrm{~m}$ below sea level (bsl; 980-1125 mbsf) in Hole 765D using the borehole televiewer (BHTV).

The use of the BHTV logging tool allowed us to conduct detailed observations of the borehole wall on a scale of centime-

\footnotetext{
${ }^{1}$ Gradstein, F. M., Ludden, J. N., et al., 1992. Proc. ODP, Sci. Results, 123: College Station, TX (Ocean Drilling Program).

2 Department of Geophysics, Stanford University, Stanford, CA 94305 , U.S.A.

${ }^{3}$ United States Geological Survey, Menlo Park, CA 94025, U.S.A.

${ }^{4}$ Present address: UNAVCO-SERIES, Campus Box 449, University of Colorado-Boulder, Boulder, CO 80309, U.S.A.
}

ters. With this information, we were able to determine the principal stress orientations as a function of depth. Regional stress orientations for the oceanic crust in the Argo Abyssal Plain (this study) and the continental shelf of western Australia (World Stress Project) are used to investigate the nature of lithosphere coupling between the oceanic and continental crust. The proximity of Site 765 to the Java Trench (Fig. 1) also enabled us to investigate to what degree the downgoing slab has dictated the stresses seaward of the trench.

\section{METHODS}

\section{Principles of Wellbore Failure}

Grough and Bell (1981) and Bell and Grough (1983) initially proposed that breakouts are spalled regions of the wellbore that develop in the direction of the least horizontal far-field stresses. It is well known that breakouts are the result of localized shearfailure around the borehole in response to the concentration of compressive stress (maximum circumferential stress) that exceeds the compressive strength of the rock (Zoback et al., 1985). Zoback et al. (1985) used a Mohr-Coulomb criterion to account for the shape of the breakout and later proposed a method of estimating the horizontal stresses if the shape or width of the breakout were well-constrained (Barton et al., 1988; Moos and Zoback, 1990).

At the borehole wall, the circumferential stress, $\sigma_{\theta \theta}$, is given by

$$
\sigma_{\theta \theta}=\mathrm{SH}_{\max }+\mathrm{Sh}_{\min }-2\left(\mathrm{SH}_{\max }-\mathrm{Sh}_{\min }\right) \cos 2 \theta-2 P_{o},
$$

where $\mathrm{SH}_{\max }$ and $\mathrm{Sh}_{\min }$ are the maximum and minimum horizontal principal stresses, respectively; the angle $\theta$ is measured with respect to the direction of the maximum horizontal principal stress; and $P_{o}$ is the pore pressure in the borehole. Under conditions of unequal horizontal principal stresses, the circumferential stress has a maximum value at $\theta= \pm \pi / 2$ and its minimum at $\theta=$ 0 , as shown in Figure 2. Wellbore breakouts therefore will form when the compressive stress concentration exceeds the compressive strength of the rock, $\mathrm{C}_{o}$, or

$$
\sigma_{\theta \theta}=\mathrm{SH}_{\max }+\mathrm{Sh}_{\min }-2\left(\mathrm{SH}_{\max }-\mathrm{Sh}_{\min }\right) \cos 2 \theta-2 P_{o} \geq C_{o},
$$




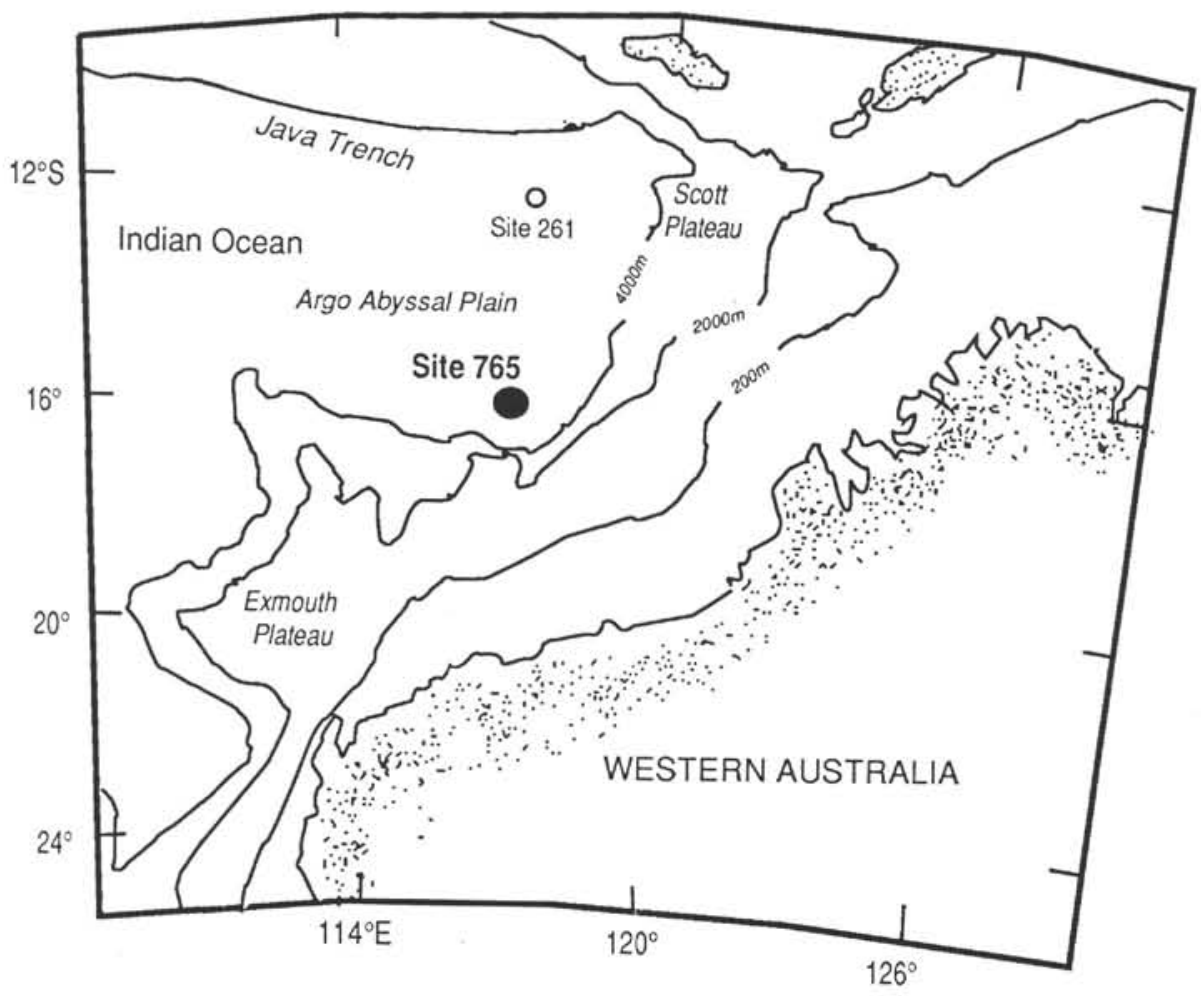

Figure 1. Location of Site 765 in the Argo Abyssal Plain.

A

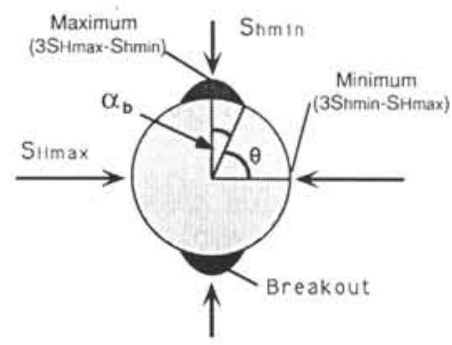

Breakout development

C

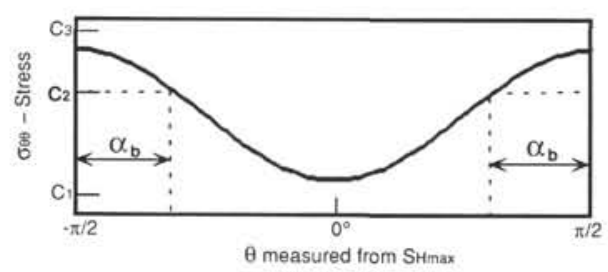

Circumferential stresses

Figure 2. A. Schematic representation of the breakout process, showing the angle of breakout extent, $\alpha_{b}$, where $\phi_{b}=\Pi / 2-\alpha_{b}$. B. BHTV data (right) over a breakout interval, where polar cross sections delineate the breakout shape. The radial lines indicate the picks of the breakout width. Breakout azimuth is the bisector of the angle $\alpha$ b. C. The variation in circumferential stress, $\sigma_{\theta \theta}$, is a function of q measured from $\mathrm{SH}_{\max }$. plotted in Figure 2B, is the case for an arbitrary horizontal stress distribution. At $\mathrm{C}_{o}=\mathrm{C}_{3}$, the borehole should be devoid of breakouts because rock strength should exceed the stress concentration everywhere around the borehole. However, at $\mathrm{C}_{o}=\mathrm{C}_{2}$, a breakout should form and expand out to $\alpha_{\mathrm{b}}$ (dashed line in Fig. 2B).

\section{Borehole Televiewer}

The BHTV is an ultrasonic well-logging tool useful for measuring the orientation and distribution of stress-induced wellbore breakouts and fractures and for analyzing lithostratigraphic assemblages. The BHTV used in the ODP community is an analog device that contains a transducer emitting a $1.4-\mathrm{MHz}$ focused $3^{\circ}$ acoustic beam at a rate of 1800 pulses/s. To attain complete azimuthal coverage of the borehole wall, the transducer rotates at about $3 \mathrm{rev} / \mathrm{s}$, while the tool logs up the hole at a speed of about $2.5 \mathrm{~cm} / \mathrm{s}$. A fluxgate magnetometer inside the tool provides orientation with respect to magnetic north. Analog data are transmitted up the co-axial logging cable and recorded on videotape for later processing.

The ultrasonic seismograms undergo an analog-to-digital conversion by windowing the reflected pulse and digitizing at $1-\mu \mathrm{s}$ intervals (Barton, 1988). This process produces both amplitude information (pertaining to the wellbore's reflectivity) and traveltime information, which is needed to determine hole geometry and to detect breakouts. The borehole geometry can best be analyzed by constructing polar cross sections for interactive selection of the breakout azimuths and breakout width (Fig. 2B).

The BHTV was run twice in Hole 765D. During the first run, the centralizing bow springs were too stiff and pressed against the borehole wall too tightly. At logging speeds of $2.5 \mathrm{~cm} / \mathrm{s}$, the tool resisted upward movement and often continued to log the same section of the hole for several seconds. Eventually, an increase in tensional stresses in the logging wire caused the tool to jerk swiftly up the hole, often bypassing large sections of the hole. 
Complete borehole coverage thus was not possible during this first run. Fortunately, smaller and more responsive bow springs were installed before the second run, enabling us to collect a near-complete log. Results of the analysis for the second run are presented here.

\section{BREAKOUT ANALYSIS}

Observations of stress-induced wellbore breakouts are limited to the basalt formation of Hole 765D, because BHTV coverage does not extend into the overlying sediments. These breakouts are clustered in three different sections of the well: 1123 to 1108 , 1046 to 1034 , and 988 to $968 \mathrm{mbsf}$. The orientations, character, and distribution of the breakouts, as well as the associated lithology of the spalled rocks, differ slightly and therefore warrant separate discussions.

\section{Interval 1 (1123-1108 mbsf)}

The deepest suite of breakouts (Interval 1) occurs within a monotonous section of aphyric pillow basalts, where both fresh and devitrified glass rinds are found on the pillows margins (Hole 765D basement Unit 15, Ludden, Gradstein, et al., 1990). Small, brecciated horizons bound some of the pillows, but poor-to-incomplete core recovery makes mapping the size of the pillows and fractured zones difficult.

In general, the breakouts within Interval 1 are of exceptional quality (Figs. 3A and 3B). Despite shortcomings of a slightly off-centered tool, first-order measurements of the breakouts show consistent orientations with depth, where breakout widths are generally less than $40^{\circ}$ (Figs. $3 \mathrm{~A}$ and $3 \mathrm{~B}$ ). A simple average for $\mathrm{SH}_{\max }$ for all 250 observations (every $2 \mathrm{~cm}$ ) is $120.1^{\circ} \mathrm{N} \pm 8.3^{\circ}$ (Figs. 4 and 5). Second-order features, occurring at wavelengths on the order of 10 to $40 \mathrm{~cm}$, include minor discontinuities in the style of wellbore failure. The borehole wall appears to alternate slightly between zones with well-developed breakouts and areas of presumably intact rock devoid of breakouts (Figs. 3A and 3B). Because significant changes in the circumferential stresses are not expected to occur at this scale, the depth variability of the breakouts may be related to small-scale changes in the compressive strength of the rock with depth. Marked increases in reflectivity occur at both the centimeter and meter scale as the log leaves a breakout interval and enters a zone of intact rock, devoid of compressive failure. Consequently, any change in reflectivity would represent a textural change in the host rock, such as a subtle transition between the margins and the center of individual pillows or brecciated zones within the pillow basalts.

\section{Interval 2 (1046-1034 mbsf)}

The intermediate breakout (Interval 2) occurs within a sparsely phyric pillow basalt section (Hole 765D basement Unit 9, Ludden, Gradstein, et al., 1990). Unit 9 is distinguished from Unit 15 by the lack of any brecciated fractures. Although, the character of the pillow margins is similar to those in Unit 15, poor core recovery $(15 \%)$ makes mapping the pillows very difficult.

The breakout widths within Interval 2 are considerably more massive and asymmetric (Figs. 3C and 3D). The side of the breakout trending $\sim 220^{\circ}$ is more than $60^{\circ}$ wide. The opposite breakout average is about $43^{\circ}$ wide. The discontinuity of the breakouts at this intermediate depth is somewhat similar to that found in the deeper section (1123 to $1108 \mathrm{mbsf}$ ). Although Interval 2 is shorter than its deeper counterpart, the orientations remain roughly consistent, showing that $\mathrm{SH}_{\max }$ is about $133.7^{\circ} \mathrm{N} \pm 12.2^{\circ}$ (Figs. 4 and 5).

\section{Interval 3 (988-986 mbsf)}

The shallowest suite of breakouts (Interval 3), and also the shortest $(2 \mathrm{~m})$, appears to have developed within a massive layer of basalt flows with intermediate layers of pillow basalts and hyaloclastic material (Hole 765D basement Unit 3, Ludden, Gradstein, et al., 1990). Because the core recovery in Core 123-765D$5 \mathrm{R}$ was complete, with many of the sections containing large coherent pieces of rock, it may be possible to identify the rocks associated with this breakout interval.

The extent of wellbore failure for this $2-\mathrm{m}$ breakout interval was slightly asymmetric, with the most pronounced breakout occurring at $180^{\circ} \mathrm{N}$ (Figs. 3E and 3F). Average widths again are about $40^{\circ}$. Aside from these small differences, the evidence for a well-developed breakout because of wellbore failure is convincing. However, the most notable difference between these breakouts and the others is the inferred $\mathrm{SH}_{\max }$ direction of $91.6^{\circ} \mathrm{N} \pm 5^{\circ}$ (Figs. 4 and 5).

No immediate explanation is available for this change in direction, but similar features have been observed at Cajon Pass, California, near the San Andreas Fault. In this deep well $(3.5 \mathrm{~km})$, major changes in the stress field have been associated with places where the wellbore has intersected faults believed to be active (Shamir and Zoback, in press).

The statistical average of all three breakout intervals was determined using circular statistics (Mardia, 1972) and by placing additional weight on the breakouts that occurred over a longer depth interval (Figs. 4 and 5). The expression that describes this method is given below,

$$
\mathrm{SH}_{w}=\frac{\sum_{i=1}^{3} L_{i} \mathrm{SH}_{i}}{\sum_{i=1}^{3} L_{i}}
$$

where $\mathrm{SH}_{w}$ is the distance-weighted average for $\mathrm{SH}_{\max }$ in this hole; $\mathrm{L}_{i}$ is the length of interval $i$; and $\mathrm{SH}_{i}$, is the average $\mathrm{SH}_{\max }$ direction for interval $i$.

For example, the deeper $15-\mathrm{m}$ interval should carry more statistical weight than the shallower $2-m$ interval. Figure 6 is a rose diagram showing the orientation for each breakout interval, as well as the distance-weighted average for the entire well. The final direction of $\mathrm{SH}_{\max }$ for this site is $121.5^{\circ} \mathrm{N} \pm 9.0^{\circ}$ (Fig. 6). If the $\mathrm{SH}_{\max }$ direction of $91.6^{\circ} \mathrm{N} \pm 5^{\circ}$ from the shallower interval were excluded from this average, the $\mathrm{SH}_{\max }$ for the site should be $126^{\circ} \mathrm{N} \pm 9.0^{\circ}$.

\section{DISCUSSION}

\section{Regional Stress Field Indicators}

Compilation of principal stress directions worldwide has provided a valuable tool with which to address the nature of plate-driving forces (Fig. 2 of Zoback et al., 1989). In particular, stress indicators from industry wells drilled in the Exmouth Plateau, southwest of Hole 765D, show an average direction of about $120^{\circ} \mathrm{N}$. This is in excellent agreement with the $121.5^{\circ} \mathrm{N} \pm 9^{\circ}$ orientation for $\mathrm{SH}_{\max }$, inferred from breakouts in Hole 765D (Fig. 7). Contemporary effects from this compressive stress direction may be found in the Exmouth and Scott plateaus near the edge of the ocean/continent boundary in northwestern Australia. These regions are associated with Holocene-age structural highs along a series of synclines that trend parallel to the northwest margin of Australia (Exon and Wilcox, 1980). The development of these north-to-northeast trending structural highs and the internal consistency in the reported $\mathrm{SH}_{\max }$ orientations for both Site 765 and the Exmouth Plateau, the Scott Plateau, and the Timor Sea (Fig. 7) suggest that the present-day stress field is responsible for these structures. Stress data from the onshore Canning Basin of western 


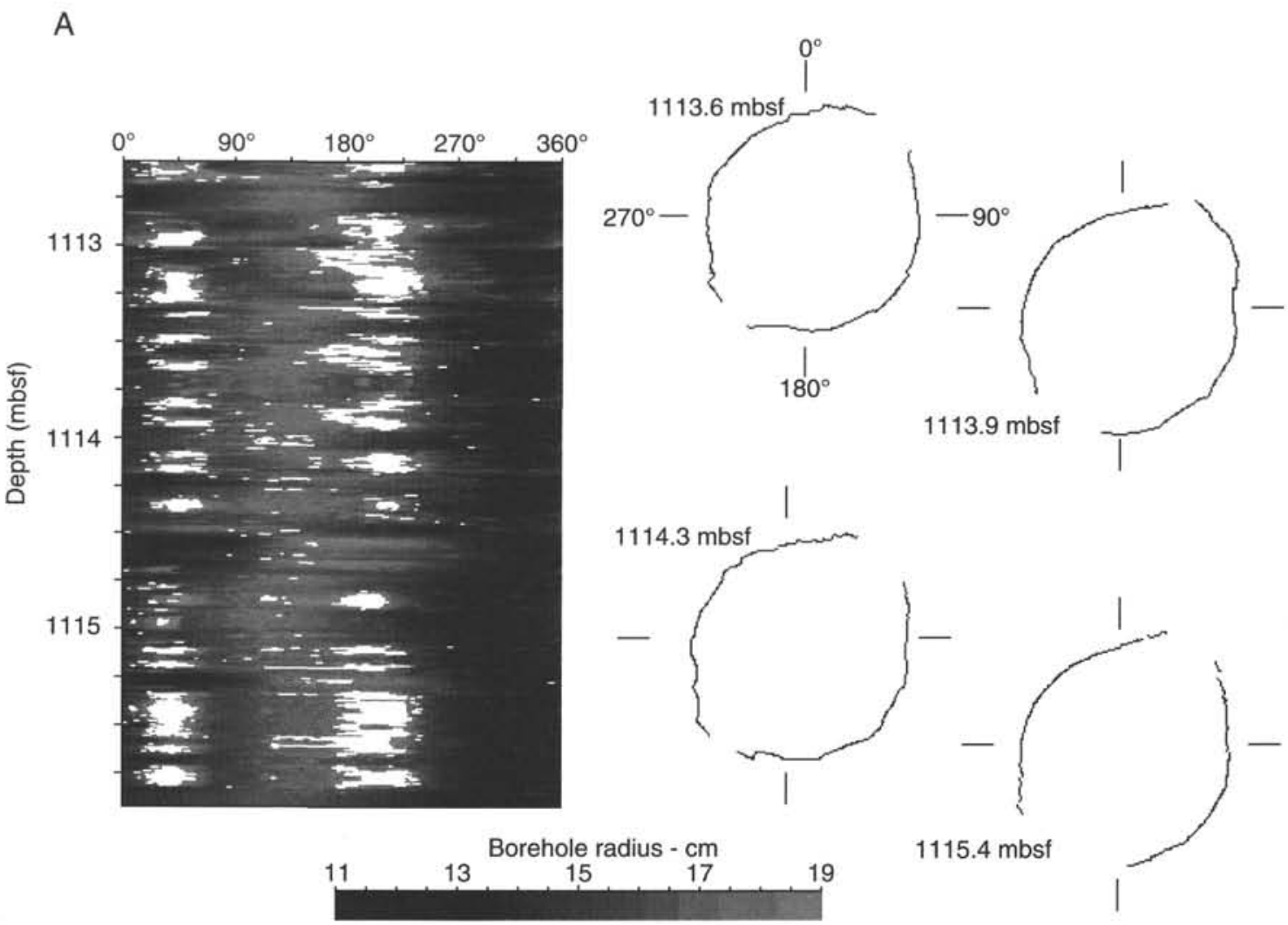

Figure 3. Borehole televiewer imagery. A. Selected (1116-1111 mbsf) BHTV images from breakout Interval 1. Color enhancements of the BHTV data are plotted by simulating an unwrapped portrait of the borehole from $0^{\circ}$ to $360^{\circ}$. The azimuth is magnetically corrected for true north. The color scheme is used to scale the borehole radius, where distances from the tool's center range from red (farthest) to purple (closest). The breakouts are represented by the vertical black-banded images on the right, representing unreflected sonic energy. B. The polar cross sections from Interval 1 clearly illustrate the borehole elongation despite the tool's being off-centered. Note the subtle changes in reflectivity between the breakout zones and the layers void of breakouts. C., D. Selected (1045-1041 mbsf) BHTV images from breakout Interval 2. Explanations for C and $\mathbf{D}$ are similar to those for $\mathbf{A}$ and $\mathbf{B}$. Note that the width of the breakouts (D) is considerably greater than that observed in Interval 1. E., F. Selected (989-983 mbsf) BHTV images from breakout Interval 3. Explanations for $\mathbf{E}$ and $\mathbf{F}$ are similar to those for $\mathbf{A}$ and $\mathbf{B}$. Note the asymmetry in the breakouts in this interval.

Australia (700 km southeast of Site 765$)$ exhibit a markedly different stress orientation of approximately $50^{\circ} \mathrm{N}$. This may be an example of a separate stress province because compressional axes ( $P$-axes) from earthquakes farther eastward revert back to a stress direction consistent with the offshore stress data (Fig. 7). The east-west trending $\mathrm{SH}_{\max }$ direction immediately south of the Java Trench should not be considered representative of intraplate stresses. This north-south $\mathrm{Sh}_{\min }$ direction inferred from the 1977 $\mathrm{M}=8.2$ Sumba normal faulting earthquake has been interpreted as either an interplate coupling event along the Java-Timor arc (Stewart, 1978; Given and Kanamori, 1980) or a plate-bending event (Hanks, 1979). Therefore, one should not rely upon the Sumba event as an indicator of intraplate stresses.

\section{Regional Seismicity}

The western section of the Australian continent is associated with high levels of seismicity (Fig. 8 and Fig. 1 of Fredrich et al., 1988). One of the largest earthquakes reported in the past $20 \mathrm{yr}$ was the 23 April 1979 Broome earthquake $(\mathrm{Ms}=5.7)$. Based on aftershocks associated with the main event, faulting was almost pure left-lateral strike-slip along a northwest-trending fault plane that dips about $80^{\circ}$ to the northeast. The focal mechanism and centroid depth $(27 \pm 3 \mathrm{~km})$ were determined from body waveform inversions (Fredrich et al., 1988). This centroid depth and esti- mates of the crustal thickness from seismic reflection data (Stagg and Exon, 1981) indicate that the event occurred within the lower crust or upper mantle. The $P$-axis from the focal mechanism solution for the Broome earthquake was $90^{\circ} \mathrm{N} \pm 5^{\circ}$, which is consistent with other large western Australian earthquakes (Fig. 8). This direction, however, is within $30^{\circ}$ of the $\mathrm{SH}_{\max }$ directions reported here.

Compressional axes of focal mechanisms of large historical earthquakes east of the Ninetyeast Ridge, within the Indo-Australian Plate, indicate northwest-southeast compression accommodated by strike-slip and thrust faulting (Weins, 1984; Weins et al., 1985; Petroy and Weins, 1989). This regional stress direction is consistent with breakout observations from Hole 765D and other breakout observations.

\section{Previous Stress Models}

The observed $\mathrm{SH}_{\max }$ direction of $120^{\circ} \mathrm{N}$ differs by about $30^{\circ}$ from the direction $\left(\mathrm{SH}_{\max }=90^{\circ} \mathrm{N}\right)$ predicted by finite-element models of Richardson (1987) and Cloetingh and Wortel (1986). Although the geometry of the two models was nearly identical, the magnitudes of the principal stresses were markedly different. Cloetingh and Wortel (1986) calculated a predominantly tensional stress field on the order of $200 \mathrm{MPa}$ in the vicinity of Site 765, while Richardson (1987) predicted tensional stresses near 10 


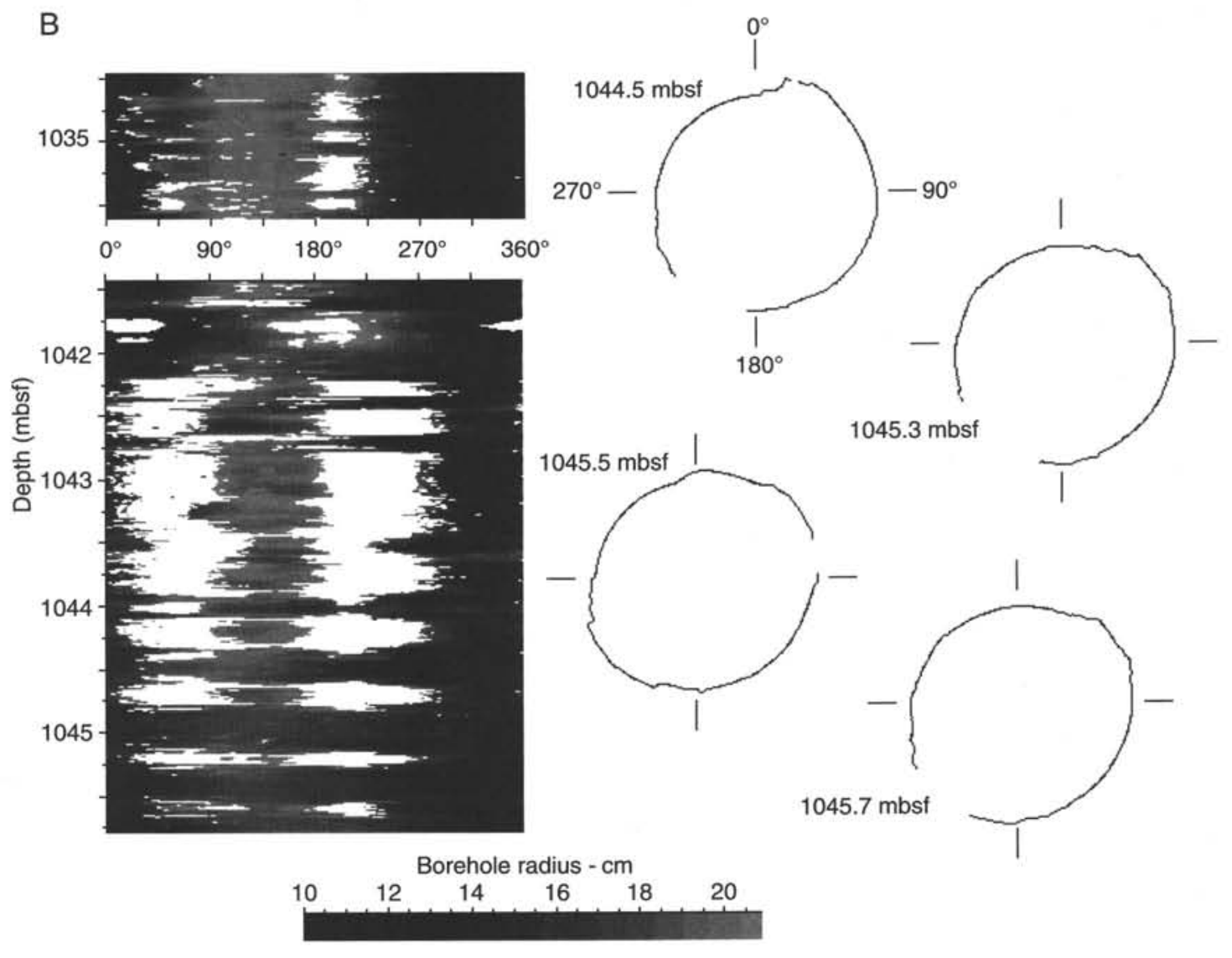

C

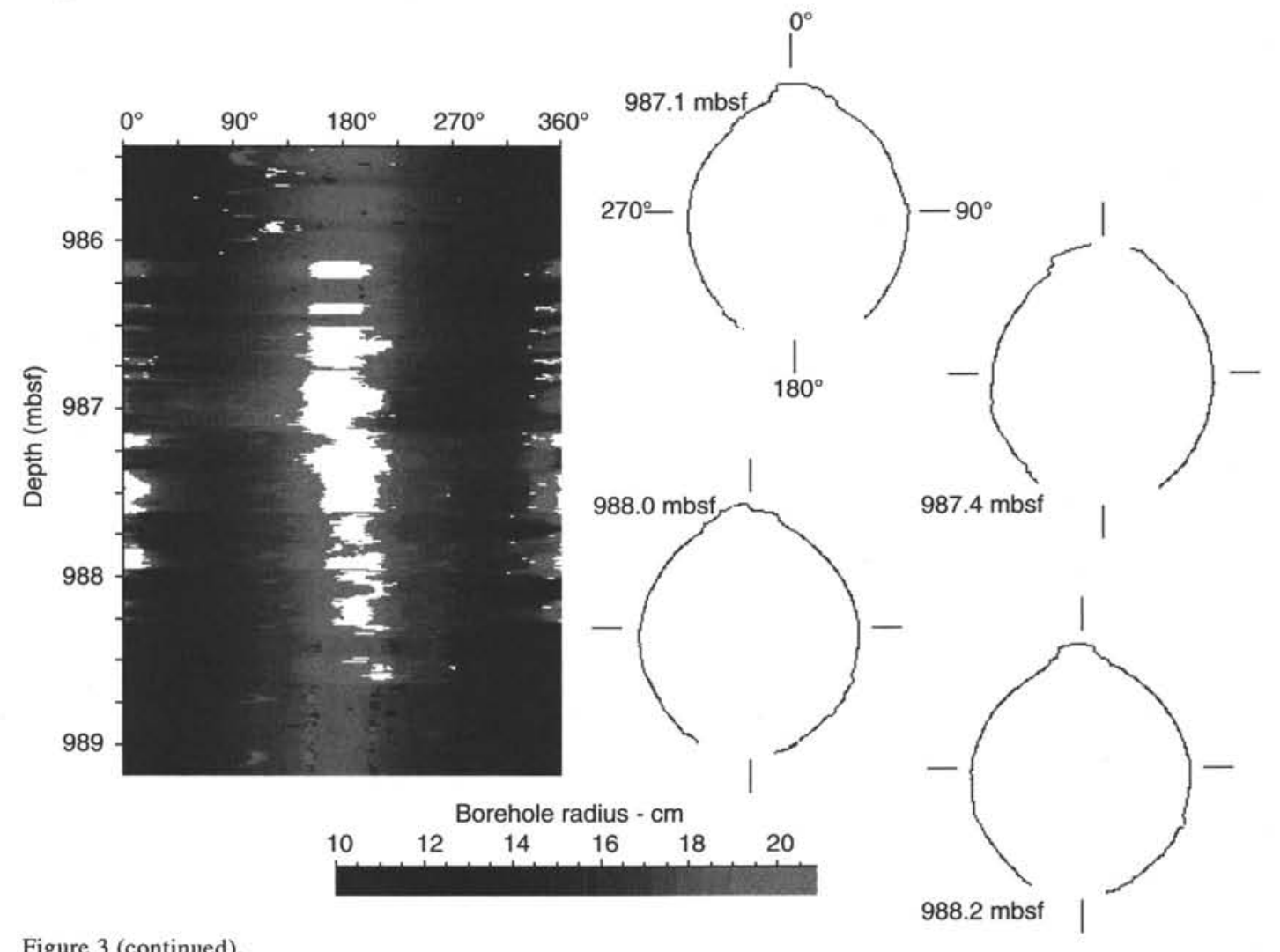




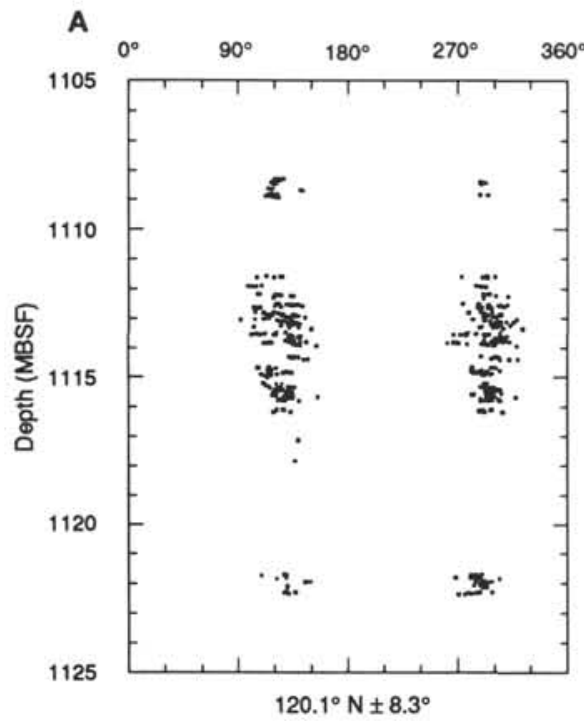

B

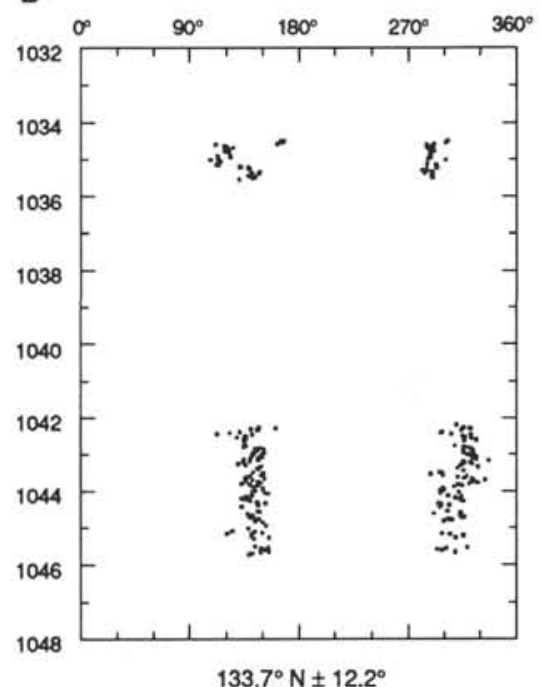

C

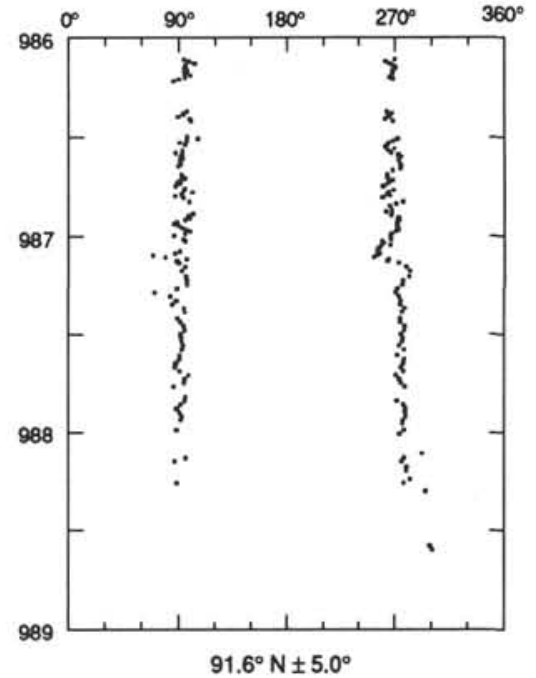

Figure 4. A detailed plot of the maximum horizontal compressive stress $\left(\mathrm{SH}_{\max }\right)$ directions inferred from wellbore breakouts from Hole $765 \mathrm{D}$. Note the changes in scale between each plot. Breakout directions were analyzed at $2.0-\mathrm{cm}$ intervals. A. 1105 to $1125 \mathrm{mbsf}$. B. 1032 to $1048 \mathrm{mbsf}$. C. 986 to 989 mbsf. Each breakout direction ( $180^{\circ}$ apart) was considered as an independent measurement for the particular breakout interval for which it was associated. The average, based on circular statistics, is indicated for each interval.

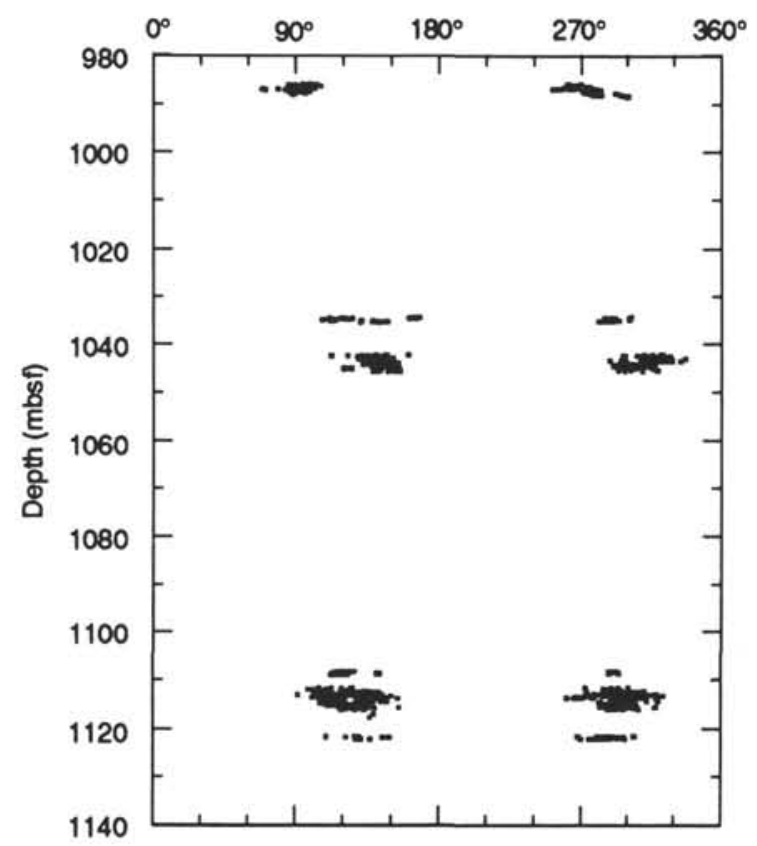

Figure 5. Overview of the maximum horizontal compressive stress $\left(\mathrm{SH}_{\max }\right)$ directions inferred from wellbore breakouts from ODP Hole 765D. The final $\mathrm{SH}_{\max }$ for Site 765 was based on circular statistics using all three breakout intervals. In addition, a weighting scheme was employed that gave more weight to the measured stress direction associated with a longer depth interval. For example, the 15 -m-long breakout in Interval 1 carried more weight than the 2 -m-long breakout in Interval 3.The result of this averaging scheme for $\mathrm{SH}_{\max }$ for Site 765 was $121.5^{\circ} \mathrm{N}$ $\pm 9^{\circ}$.

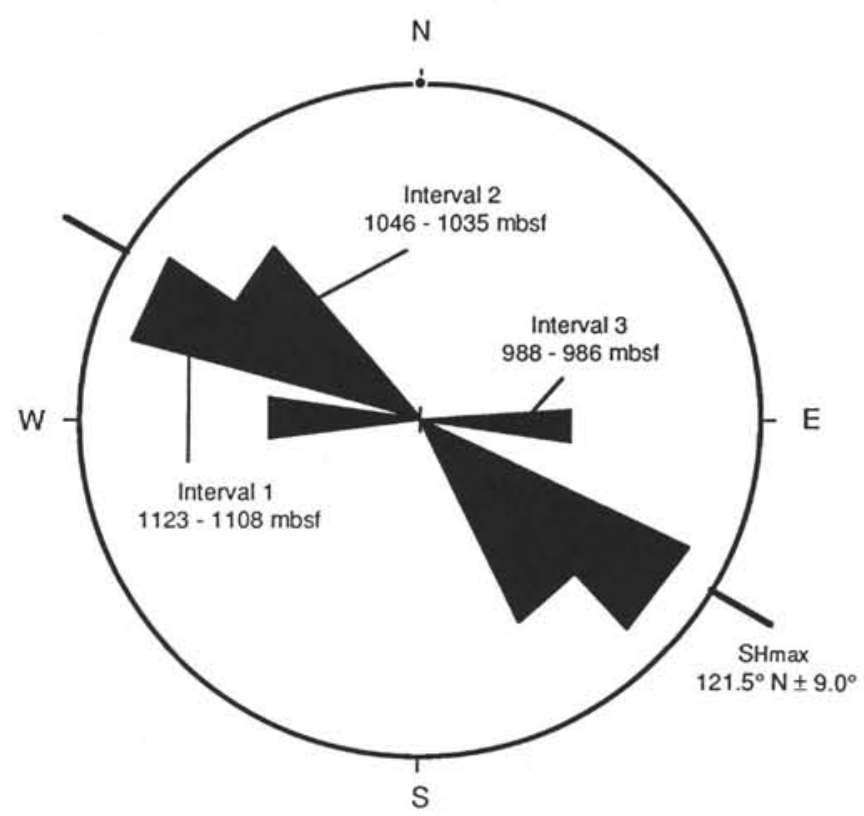

Figure 6. Rose diagram of the azimuthal variation with depth in $\mathrm{SH}_{\max }$ determined from breakouts in Hole 765D. The relative lengths of each group represent different weighting schemes, based on the distance across which the breakouts were observed. Based on Equation 3, the effective weighted-distance average for the entire well is $121.5^{\circ} \pm 9^{\circ} \mathrm{N}$. 


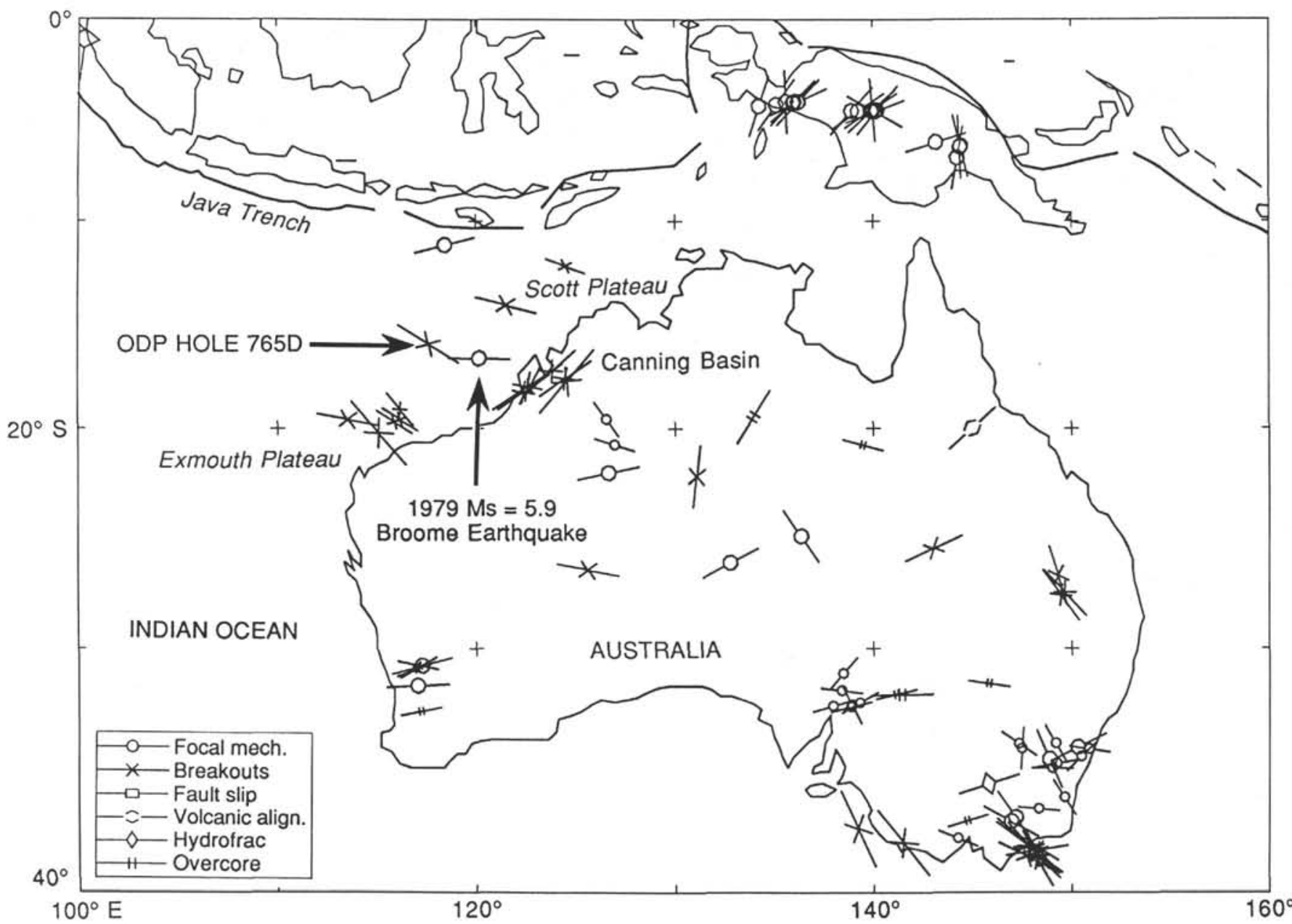

Figure 7. Regional stress map of the Indo-Australian Plate showing the orientations of the maximum horizontal compressive stress $\left(\mathrm{SH}_{\max }\right)$, based on a variety of stress indicators (Zoback et al., 1989). These indicators include wellbore breakouts from industry wells, $P$-axes from well-constrained earthquake focal mechanism solutions, hydraulic-fracturing experiments in wells, and geologic features (such as dike alignments). The results from Hole $765 \mathrm{D}$ indicate that the principal stress direction at this site is about $121.5^{\circ} \mathrm{N} \pm 9.0^{\circ}$. The $1979 \mathrm{Ms}=5.7$ Broome earthquake used here was located about $300 \mathrm{~km}$ east of Site 765 .

$\mathrm{MPa}$. Each of these models placed varying emphasis on the forces distributed throughout the plate, as well as the forces acting along the boundaries. The modeled plate-driving and resisting forces included ridge-push, slab-pull, slab-resistant, and collisional forces at the boundaries and basal drag forces.

Unfortunately, attempts to distinguish between these two markedly different stress models by in-situ measurements of stress magnitudes within the oceanic crust of Hole 765D were unsuccessful. However, what follows is an attempt to constrain the relative magnitudes of the principal stresses active at Site 765, using information about the depth of breakouts, generalized assumptions about the compressive strength of basalt, and focal mechanism solutions from regional earthquake data.

\section{ADDITIONAL CONSTRAINTS ON THE STATE OF STRESS}

Although the stress orientation determined from BHTV data in Hole 765D can be considered as one observation, it is important to emphasize that this orientation is consistent with other stress orientations observed in nearby industry wells (Fig. 7). Consequently, we use the Hole 765D breakout information to constrain the current stress field and to make generalized estimates of stress magnitudes expected in this section of the Indo-Australian Plate. Two independent criteria are used to develop these stress-regime constraints: the occurrence of breakouts and linear stress relation $(\phi)$, which describes the relative relationship between the three principal stress magnitudes. The ideal situation might be to determine stress magnitudes from hydraulic fracturing experiments, but an attempt to do this during Leg 123 was unsuccessful.

\section{Breakout Method}

Moos and Zoback (1990) successfully placed constraints on the occurrence of breakouts in relatively young oceanic crust at DSDP Hole 395A and ODP Hole 504B. Following their approach, we use the criterion for wellbore failure and estimates of the compressive strength of oceanic basalts (Bauer and Handin, 1985) to constrain the relative principal stress magnitudes.

Estimates of the principal stress magnitudes, and therefore the stress regime, are based on the assumption that one of the principal stresses is vertical and equivalent to the overburden load $\left(\mathrm{S}_{\mathrm{v}}\right)$ and that the remaining two principal stresses are horizontal $\left(\mathrm{SH}_{\max }\right.$ and $\left.\mathrm{Sh}_{\min }\right)$. We further assume, as suggested by Sibson (1974), that the ratio of the effective maximum to effective minimum 


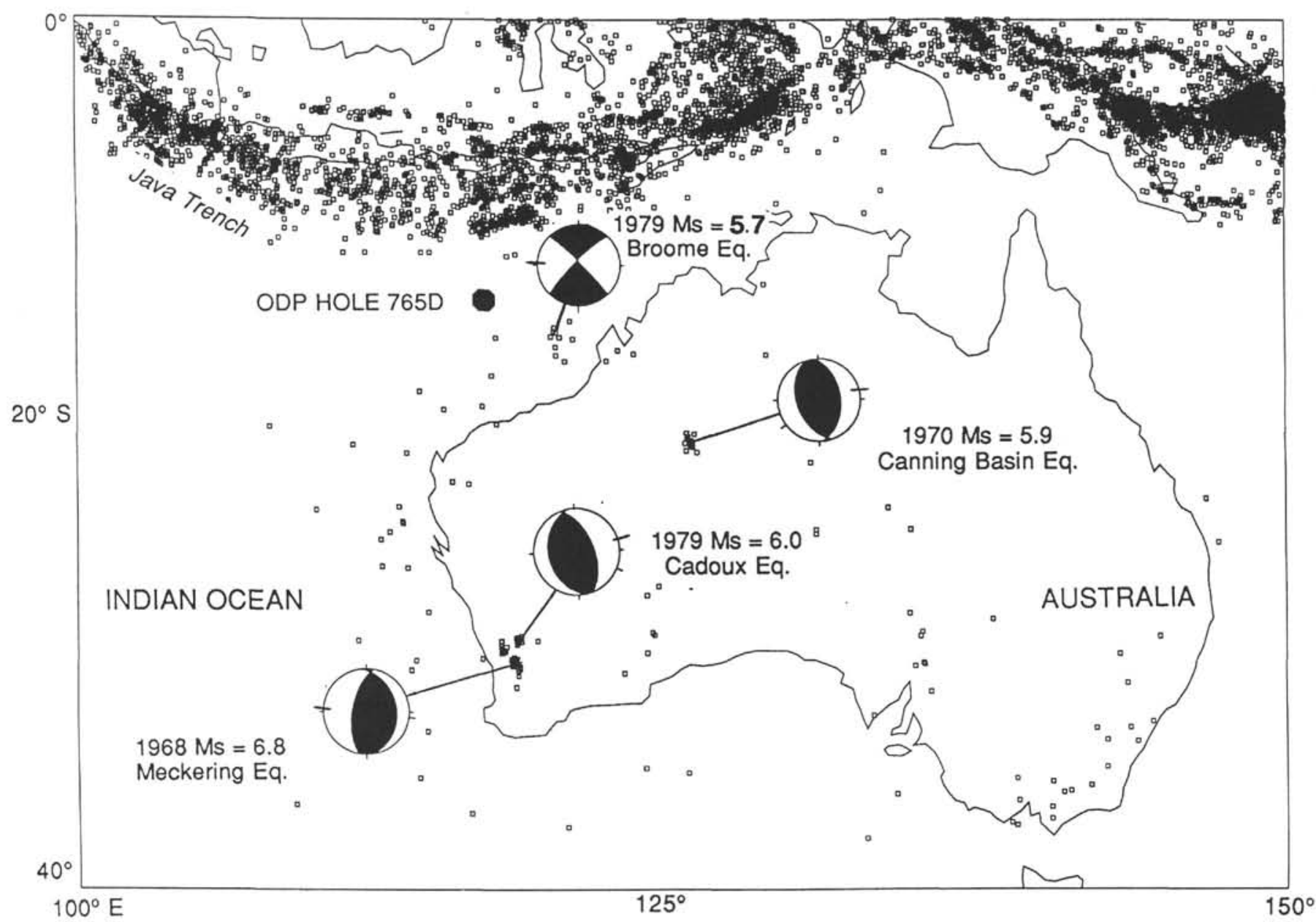

Figure 8. Epicenters of the major earthquake clusters that have occurred in western Australia and surrounding offshore areas for the period 1964 to 1987. Data are from the International Seismic Centre (ISC). Focal plane solutions for the major earthquakes are indicated with the compressional quadrants filled. The $P$-axis (tick mark) is shown bisecting the dilatational quadrant. The $1979 \mathrm{Ms}=5.7$ Broome earthquake used here was located about $300 \mathrm{~km}$ east of Site 765 (after Fredrich et al., 1988).

stresses cannot exceed that required to cause slip on preexisting faults optimally oriented with the stress field. If the above assumptions are correct, the stress constraint for any stress regime can be described in the following manner (Jeager and Cook, 1979):

$$
\left(S_{1}-P_{o}\right) /\left(S_{3}-P_{o}\right)=\left[\left(1+\mu^{2}\right)^{1 / 2}+\mu\right]^{2},
$$

where $S_{1}, S_{3}$, and $P_{o}$ are the maximum principal stress, minimum principal stress, and pore pressure, respectively, and $\mu$ is the coefficient of friction for preexisting fault planes. In seismically active regions, in-situ stress measurements using hydraulic fracturing techniques have confirmed that these constraints on stress magnitudes are generally correct (McGarr, 1980; Zoback and Healy, 1984).

Anderson's faulting theory (Anderson, 1951) implies the following relationship between the observed style of faulting and the state of stress regimes: in a normal faulting stress regime $S_{\mathrm{v}}>$ $\mathrm{SH}_{\max }>\mathrm{Sh}_{\min }$; in a strike-slip faulting stress regime, $\mathrm{SH}_{\max }>S_{\mathrm{v}}$ $>\mathrm{Sh}_{\min }$; and in a reverse faulting stress regime, $\mathrm{SH}_{\max }>\mathrm{Sh}_{\min }>$ $S_{\mathrm{v}}$.

We used $\mu=0.8$ in Equation 3 for a depth of $1125 \mathrm{mbsf}$ (occurrence of deepest breakouts) to make reasonable estimates of the minimum and maximum stress magnitudes for both normal and reverse faulting regimes. For the strike-slip faulting case, we assume that $S_{\mathrm{v}}=\left(S_{1}+S_{3}\right) / 2$. For reference, the vertical overburden was determined using seawater, sediment, and basalt densities of 1020,2200 , and $2850 \mathrm{~kg} / \mathrm{m}^{3}$, respectively. We used a water depth of $5724 \mathrm{~m}$ and a sediment thickness of $932 \mathrm{~m}$. For completeness, Table 1 shows the variation of stresses for the three possible stress regimes using a range of $\mu$-values (i e., $\mu=0.6,0.8$, and 1.0). Only in the strike-slip regime are both horizontal stresses estimated from Equation 4.

For the special case of a normal faulting stress regime, where $S_{v}=S_{1} \sim S_{2}$, the condition is such that both normal and strike-slip earthquakes will occur on optimally oriented faults. For example, dipping faults whose strike is approximately near-perpendicular to the $\mathrm{Sh}_{\min }$ (or $S_{3}$ ) direction will be associated with normal faulting events. On the other hand, vertical faults oriented about $45^{\circ}$ to the same principal horizontal stress directions will experience strike-slip faulting. For a reverse faulting stress regime, where $S_{v}=S_{3} \sim S_{2}$, the condition is such that both reverse and strike-slip earthquakes will occur on optimally oriented faults. In this case, dipping faults whose strike is approximately near-perpendicular to $\mathrm{SH}_{\max }$ (or $\mathrm{S}_{1}$ ) direction will be associated with reverse faulting events. On the other hand, vertical faults again oriented about $45^{\circ}$ to the two principal horizontal stress directions will experience strike-slip faulting. 
Table 1. Stress calculations (based on Eq. 4) evaluated at a depth of $1123 \mathrm{mbsf}$, the location of the deepest breakouts.

\begin{tabular}{|c|c|c|c|c|c|c|c|c|c|c|c|}
\hline $\begin{array}{l}\text { Stress regime: } \\
\text { Stress unit (MPa): }\end{array}$ & $S_{v}{ }^{d}$ & $\mathrm{P}_{\mathrm{o}}{ }^{\mathrm{e}}$ & $\mathrm{S}_{1}$ & $\begin{array}{c}\mu=0.6 \\
S_{2}\end{array}$ & $\mathrm{~S}_{3}$ & $S_{1}$ & $\begin{array}{c}\mu=0.8 \\
\mathrm{~S}_{2}\end{array}$ & $\mathrm{~S}_{3}$ & $\mathrm{~S}_{1}$ & $\begin{array}{c}\mu=1.0 \\
S_{2}\end{array}$ & $\mathrm{~S}_{3}$ \\
\hline $\begin{array}{l}{ }^{a} \text { Normal } \\
\qquad S_{y}=S_{1} \geq S_{2} \geq S_{3}\end{array}$ & 82.5 & 68.4 & 82.5 & 82.5 & 72.9 & 82.5 & 82.5 & 71.6 & 82.5 & 82.5 & 70.8 \\
\hline $\begin{array}{l}\text { bStrike-slip } \\
\qquad \mathrm{S}_{1}>\mathrm{S}_{\mathrm{y}}=\mathrm{S}_{2}>\mathrm{S}_{3} \\
\mathrm{~S}_{\mathrm{y}}=\left(\mathrm{S}_{1}+\mathrm{S}_{3}\right) / 2\end{array}$ & 82.5 & 68.4 & 89.8 & 82.5 & 75.2 & 91.3 & 82.5 & 73.7 & 92.5 & 82.5 & 72.5 \\
\hline $\begin{array}{l}{ }^{c} \text { Reverse } \\
\quad S_{1}>S_{2} \geq S_{v}=S_{3}\end{array}$ & 82.5 & 68.4 & 112.4 & 82.5 & 82.5 & 129.4 & 82.5 & 82.5 & 150.6 & 82.5 & 82.5 \\
\hline
\end{tabular}

Note: Three different $\mu$-values illustrate the small variability of stress magnitudes for the normal and strike-slip stress regimes; however, for the case of a reverse stress regime, variability is high. The circumferential stresses shown in Figures $9 \mathrm{~B}$ and 10 are based on these tabulated stresses (only $\mu=0.8$ ) and Equation 1.

a $\mathrm{Sh}_{\min }=S_{3}, \mathrm{SH}_{\max }=S_{2}, S_{v}=S_{1}$.

b $\mathrm{Sh}_{\min }=S_{3}, S_{v}=S_{2}, \mathrm{SH}_{\max }=S_{1}$.

c $S_{y}=S_{3}, S_{\text {min }}=S_{2}, S_{\max }=S_{1}$.

${ }^{d}$ Vertical overburden at 6847 mbsl: $\rho$ seawater $=1.02 \times 10^{3} \mathrm{~kg} / \mathrm{m}^{3}$, thickness $=5724 \mathrm{~m}, \rho$ sediment $=2.20 \times 10^{3} \mathrm{~kg} / \mathrm{m}^{3}$,

thickness $=932 \mathrm{~m}$, $\rho$ basalt $=2.85 \times 10^{3} \mathrm{~kg} / \mathrm{m}^{3}$, thickness $=191 \mathrm{~m}$.

${ }^{\mathrm{e}}$ Hydrostatic pore pressure at $6847 \mathrm{mbsl}$ : $\rho_{\text {seawater }}=1.02 \times 10^{3} \mathrm{~kg} / \mathrm{m}^{3}$, thickness $=6847 \mathrm{~m}$.

Finally, given these assumptions and the values in Table 1, we use Equation 1 to compute the circumferential stresses around the borehole for normal, strike-slip, and reverse faulting stress regimes at the depth where breakouts developed (1125 mbsf) in Hole $765 \mathrm{D}$. Figure 9 illustrates that the maximum circumferential stress around the borehole occurs at $\theta= \pm 90^{\circ}$, when measured with respect to the $\mathrm{SH}_{\max }$ direction. Recall that the criterion for wellbore failure occurs when the circumferential stress exceeds compressive strength of the rock. Strength measurements performed by Bauer and Handin (1985) for basalts from Hole 504B indicated that the uniaxial compressive strength, $\mathrm{C}_{0}$, of basalt varied from about 100 to $250 \mathrm{MPa}$. If these measurements are reasonable for oceanic basalts in general, then breakouts should occur only under stress regimes optimal for both reverse and strike-slip faulting. Wellbore failure under normal/strike-slip faulting conditions should require $\mathrm{C}_{\mathrm{o}}$ to be less than $40 \mathrm{MPa}$, which is unlikely (Bauer and Handin, 1985).

\section{Linear Stress Relation $(\phi)$}

Inferring principal stress directions from focal mechanisms is not an exact indicator of stress direction (McKenzie, 1969). This method cannot account for the relative magnitude of the intermediate stress, which dictates the slip direction under triaxial stress conditions (see Zoback, 1989). But the value of intermediate stress with respect to maximum and minimum principal stresses can be expressed in the following linear stress relationship that describes relative stress magnitudes:

$$
\varphi=\left(S_{2}-S_{3}\right) /\left(S_{1}-S_{3}\right),
$$

where $S_{1}$ is the maximum principal stress, $S_{2}$ is the intermediate principal stress, and $S_{3}$ is the minimum principal stress (all stresses are compressive). Note that $\phi$ can range from zero $\left(\mathrm{S}_{2}=\right.$ $\left.\mathrm{S}_{3}\right)$ to $1\left(\mathrm{~S}_{1}=\mathrm{S}_{2}\right)$.

Several techniques have been recently developed that invert earthquake focal mechanism solutions within a specific geographic area for the principal stress directions and the corresponding $\phi$-value (Angelier, 1979; Gephart and Forsyth, 1984; Michael, 1984, 1987; Reches, 1987). The common objective in each of these inversion schemes is to arrive at the optimal stress tensor that minimizes the angle between the observed slip vector from the focal mechanism solution and the direction of maximum resolved shear stress on that fault plane. A technique was also developed to determine stress orientations from geologically determined slip directions on exhumed faults (Angelier, 1979;
Michael, 1984; Reches, 1987). Two critical assumptions enter into the inversion technique. First, that the directions of slip corresponding to the direction of maximum resolved shear stress on active fault planes for a given region are similar; and second, that a regional state of stress is responsible for all the earthquakes (or slip vectors from exhumed faults). This appears to be the case in western Australia where stress directions inferred from wellbore breakouts (Fig. 7) are consistent with stress directions inferred from earthquakes in the region (Figs. 7 and 8).

Determining the $\phi$-value can be simplified if the principal stress orientations are already well established from an independent source (e.g., stress-induced breakouts) and the slip vector is well-constrained from focal mechanism solutions. It is important to recognize that any observed $\mathrm{SH}_{\max }$ direction is not immediately constrained to be associated with any particular stress regime. Rather, it is the observed slip direction, obtained from focal mechanisms corresponding to the direction of maximum shear stress along the fault plane, that must be consistent with the stress regime.

Forward modeling for determining the corresponding $\phi$-value following Angelier's technique (1979) was used on the 23 April 1979 Broome $(\mathrm{Ms}=5.7)$ earthquake located about $300 \mathrm{~km}$ east of Site 765 so as to match the stress regime type with the slip vector determined by Fredrich et al. (1988). This 1979 earthquake was associated with left-lateral slip along a northwest-trending fault plane that dips about $80^{\circ}$ to the northeast and has a rake of about $10^{\circ}$. Initially, two possible scenarios were tested: (1) strike-slip faulting and (2) reverse faulting. The strike-slip case implies that the $\mathrm{SH}_{\max }$ direction of $121^{\circ} \mathrm{N}$ (this study) corresponded to $\mathrm{S}_{1}$ and that the $\mathrm{S}_{3}$ direction was $31^{\circ} \mathrm{N}$. The reverse faulting case again implies $\mathrm{SH}_{\max }=\mathrm{S}_{1}$, but this time, $\mathrm{S}_{3}=\mathrm{S}_{\mathrm{v}}$. Considering uncertainties in $\mathrm{SH}_{\max }$ (i.e., $121^{\circ} \pm 9^{\circ}$ ), the reverse faulting case yields $\phi$-values that range from 0.09 to 0.15 . This implies that $S_{2} \sim S_{3}=$ $\mathrm{S}_{\mathrm{v}}$ and a stress regime suitable for the generation of both strikeslip and reverse faulting events along optimally oriented faults, as discussed above. Using the same uncertainties in $\mathrm{SH}_{\max }$, the pure strike-slip faulting case yields $\phi$-values that range from -0.11 to -0.22 . Although the $\phi$-value for the pure strike-slip case was small and negative, it is difficult to distinguish unequivically between the pure strike-slip and the reverse cases. From Equation 5 , a zero $\phi$ for both stress regime cases implies that both reverse and strike-slip faulting probably should occur within the same region because $\mathrm{Sh}_{\min } \sim \mathrm{S}_{\mathrm{v}}$. Because $\phi$ can only vary from zero to 1 , it appears that the stress state that best supports the 1979 Broome event is the reverse/strike-slip stress regime. This con- 
A
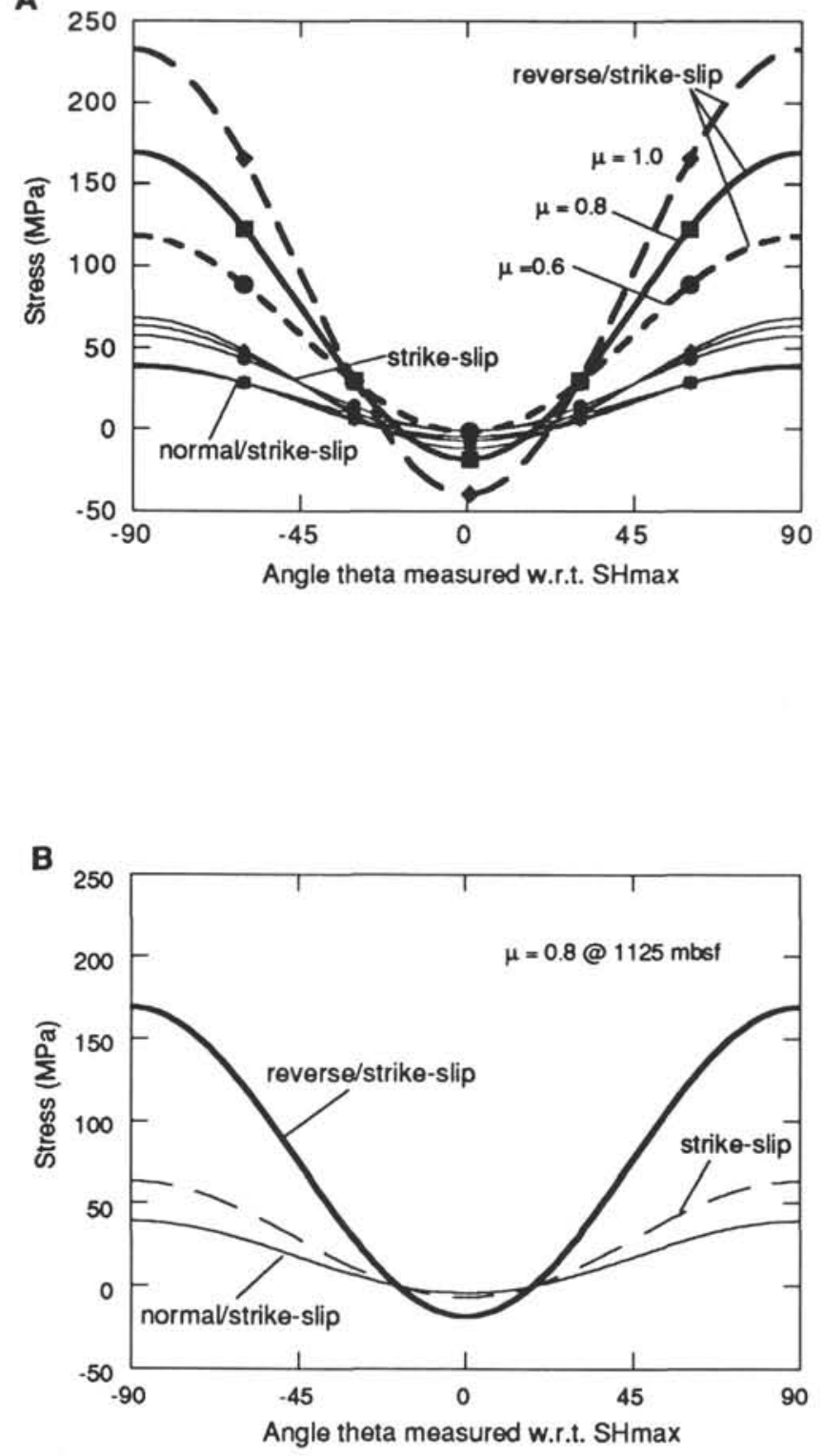

Figure 9. A. Plot of the circumferential hoop stresses (in MPa) as a function of angle $\theta$ from the $\mathrm{SH}_{\max }$ direction. The nine curves correspond to the estimated stresses for normal/strike-slip, strike-slip, and reverse/ strike-slip faulting stress regimes using coefficients of friction of $\mu=0.6$, 0.8, and 1.0, respectively, in Equation 4. See text and Table 1 for details about stress computations. B. Plot of the circumferential hoop stresses (in $\mathrm{MPa}$ ) as a function of angle $\theta$ from the $\mathrm{SH}_{\max }$ direction., using a $\mu$-value of 0.8 . Note: if the compressive strength $\left(C_{\mathrm{o}}\right)$ of basalt falls within the range of 100 to $250 \mathrm{MPa}$, breakouts should be expected to develop only under reverse/strike-slip and/or pure strike-slip faulting conditions, with $\phi \sim 0$. Normal faulting stress regimes could not generate the appropriate stress concentrations to cause wellbore breakouts.

clusion is consistent with the occurrence of both styles of faulting seen in western Australia (Fig. 8). Additional in-situ data and large earthquakes might further constrain the state of stress in the area. The same test for $\phi$-values for a normal faulting stress regime $\left(\mathrm{S}_{\mathrm{v}}=\mathrm{S}_{1}\right.$ and $\left.\mathrm{S}_{3}=31^{\circ} \mathrm{N}\right)$ produced results far outside the allowable $\phi=0$ to $\phi=1$ range.

Figure 10 illustrates the circumferential stress distribution for a reverse faulting stress regime with $\phi$ ranging from zero to 1 . The

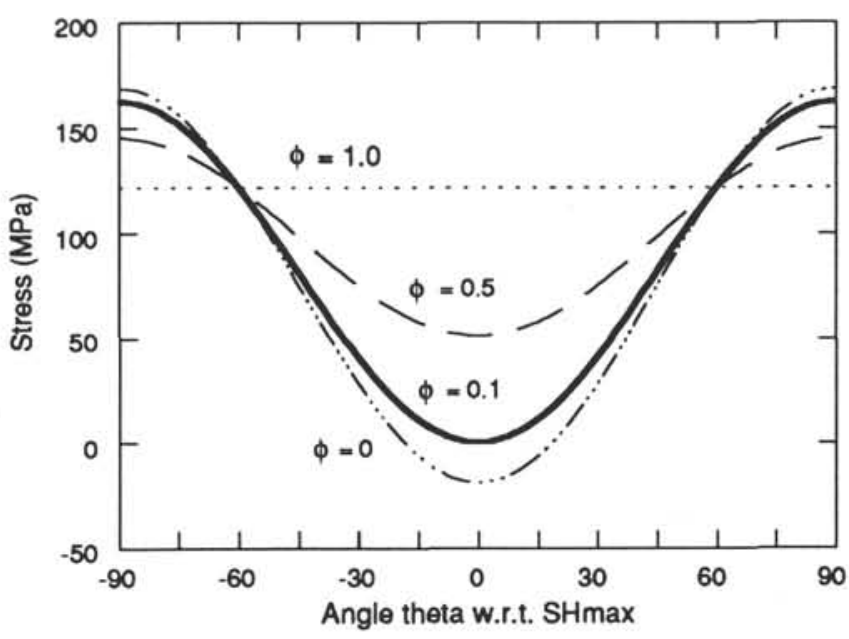

Figure 10. Plot of the circumferential hoop stresses (in MPa) as a function of angle $\theta$ from the $\mathrm{SH}_{\max }$ direction. Curves correspond to estimated stresses for a reverse/strike-slip faulting case for $\phi$ ranging from zero to 1 . The curve $\phi=0.1$ is the result of matching the regional stress field to the slip vector reported for the $1979 \mathrm{Ms}=5.9$ Broome earthquake (see text for details). Note that for the case of $\phi=1.0$, should the compressive strength be less than $125 \mathrm{MPa}$, breakouts should develop omni-directionally, because equivalent horizontal stresses produce no stress concentration.

$\phi=0.1$, from the above tensor calculation, is included for clarification. When $\phi=1.0$, both horizontal stresses should be equivalent, and breakouts should be omni-directional if the compressive strength of the basalt were less than $125 \mathrm{MPa}$. Although speculative at this stage, the spatial distribution of these stress-induced breakouts suggests that the compressive strength of basalt appears to fluctuate about the average maximum circumferential stress concentration. A detailed compressive strength "log" of the core samples from this hole will be required to verify the exact stress state.

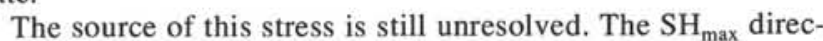
tion is oblique to the absolute plate motion vector (Minster and Jordon, 1978; DeMets et al., 1990), suggesting that stresses are not responding completely to basal drag and ridge-push as the plate moves northward toward the Java Trench. The proximity of the Australian continental margin to the Java Trench may be a secondary source of drag forces that acts to resist northward plate motion. However, the tensional stresses imposed by trench-pull forces at the Java Trench appear not to be transmitted far into the interiors of the Indo-Australian Plate.

\section{CONCLUSIONS}

Detailed BHTV analyses from Hole 765D in the southern limit of the Argo Abyssal Plain in the Indian Ocean northwest of the Australian continental margin show that the maximum horizontal compressive stress $\left(\mathrm{SH}_{\max }\right)$ direction is about $121.5^{\circ} \mathrm{N} \pm 9^{\circ}$. This stress direction is consistent with other stress indicators from offshore industry wells in the Exmouth and Scott plateaus. Considering the criterion for wellbore failure and the compressive strength of basalt, the breakouts observed in Hole 765D support the interpretation that the northeast Indo-Australian Plate south of Java and northwest of Australia is in a state of compression. Stress-tensor calculations using the slip vector determined from bodywave inversion of the $1979 \mathrm{Ms}=5.7$ Broome left-lateral strike-slip earthquake (Fredrich et al., 1988) along with the assumption that the stress tensor at Site 765 is similar to that of the earthquake ( $300 \mathrm{~km}$ from Site 765 ) also suggest that northwestern Australia is in a state of compression with intermediate stress $\left(S_{2}\right.$ 
or $\mathrm{Sh}_{\min }$ ) being approximately equivalent to the vertical overburden $\left(S_{\mathrm{v}}\right)$. These results are supported by the widespread occurrence of both strike-slip and reverse-type earthquakes in the northwest section of the Indo-Australian Plate in western Australia. However, a tensional state of stress for this section of the Indo-Australian Plate has been predicted (Cloetingh and Wortel, 1986; Richardson, 1987). The occurrence of breakouts suggests that a tensional stress field might not produce the stress concentration suitable for the formation of breakouts, because the compressive stress concentration along the borehole wall might never exceed the compressive strength of the basalt.

\section{ACKNOWLEDGMENTS}

We thank the crew of the JOIDES Resolution and the supporting ODP staff for making this research possible. Special thanks to C. Barton for developing the software for BHTV analyses. We also thank M. D. Zoback, G. Shamir, D. Moos, and C. Barton for their help with the reduction and analysis of data and M. L. Zoback for the use of her program for determining the $\phi$-value. We extend our appreciation to M. Magee, M. L. Zoback, and M. D. Zoback for their assistance with the World Stress Data Base. We also thank G. Beroza for his assistance with generating the seismicity map from ISC data. The authors thank D. Wiens, M. Magee, C. Barton, T. Parsons, and an anonymous reviewer for greatly improving this manuscript.

\section{REFERENCES}

Anderson, E. M., 1951. The Dynamics of Faulting and Dike Formation with Applications in Britain (2nd ed.): Edinburgh (Oliver and Boyd),

Angelier, J., 1979. Determination of the mean principal directions of stresses for a give fault population. Tectonophysics, 56:T17-T26.

Barton, C. A., 1988. Development of in-situ stress measurement techniques for deep drillholes [Ph.D. dissert.]. Stanford Univ., Stanford.

Barton, C. A., Zoback, M. D., and Burns, K. L., 1988. In-situ stress orientation and magnitude at the Fenton Geothermal site, New Mexico, determined from wellbore breakouts. Geophys. Res. Lett., 15: 467-470.

Bauer, S. J., and Handin, J., 1985. Mechanical properties of basalt cores from Deep Sea Drilling Project Hole 504B. In Anderson, R. N., Honnorez, J., Becker, K., et al., Init. Repts. DSDP, 83: Washington (U.S. Govt. Printing Office), 371-378.

Bell, J. S., and Gough, D. I., 1983. Northeast-southwest compressive stress in Alberta: evidence from oil wells. Earth Planet. Sci. Lett., $45: 475-482$.

Bergman, E. A., and Solomon, S. C., 1985. Earthquake source mechanisms from body-waveform inversion and intraplate tectonics in the northern Indian Ocean. Phys. Earth Planet. Inter., 40:1-123.

Cloetingh, S.A.P.L., and Wortel, M.J.R., 1986. Stress in the Indo-Australian Plate. Tectonophysics, 132:49-67.

Demets, C., Gordon, R. G., Argus, D. F., and Stein, S., 1990. Current plate motions. Geophys. J. Int., 101:425-478.

Exon, N. F., and Willcox, J. B., 1980. The Exmouth Plateau: stratigraphy, structure and petroleum potential. Bull. Bur. Miner. Resour., Geol. Geophys. (Aust.), No. 199.

Fredrich, J., McCaffery, R., and Denham, D., 1988. Source parameters of seven large Australian earthquakes determined by body waveform inversion. Geophys. J., 95:1-13.

Gephart, J. W., and Forsyth, D. W., 1984. An improved method for determining the regional stress tensor using earthquake focal mechanism data: application to the San Fernando earthquake sequence. $J$. Geophys. Res., 89:9305-9320.

Given, J. W., and Kanamori, H., 1980. The depth extent of the 1977 Sumbawa Indonesian earthquake. Eos, 61:1044. (Abstract)

Grough, D. I., and Bell, J. S., 1981. Stress orientations from oil well fractures in Alberta and Texas. Can. J. Earth Sci., 18:1358-1370.

Hanks, T. C., 1979. Deviatoric stresses and earthquake occurrence at the outer rise. J. Geophys. Res., 84:2343-2347.
Hickman, S. H., Svitek, J. F., Langseth, M. G., 1984. Borehole televiewer $\log$ of Hole 395A, In Hyndman, R. D., Salisbury, M. H., et al., Init. Repts. DSDP, 78B: Washington (U.S. Govt. Printing Office), 709 715 .

Jeager, J. C., and Cook, N.G.W., 1979. Fundamentals of Rock Mechanics (3rd ed.): New York (Chapman and Hall).

Ludden, J. N., Gradstein, F. M., et al., 1990. Proc. ODP, Init. Repts., 123: College Station, TX (Ocean Drilling Program).

Mardia, K. V., 1972. Statistics of Directional Data: London'(Academic Press). McAdoo, D. C., and Sandwell, D. T., 1985. Folding of oceanic lithosphere. J. Geophys. Res., 90:8563-8568.

McGarr, A., 1988. On the state of lithospheric stress in the absence of applied tectonic forces. J. Geophys. Res., 93:13609-13617.

McKenzie, D. P., 1969. The relationship between fault plane solutions for earthquakes and the directions of the principal stresses. Bull. Seismol. Soc., 59:591-601.

Michael, A. J., 1984. Determination of stress from slip data: faults and folds. J. Geophys. Res., 89:11517-11526.

1987. The use of focal mechanisms to determine stress: a control study. J. Geophys. Res., 92:357-368.

Minster, J. B., and Jordan, T. H., 1978. Present-day plate motions. J. Geophys. Res., 83:5331-5354.

Moos, D., and Zoback, M. D., 1990. Utilization of observations of well bore failure to constrain the orientation and magnitude of crustal stresses: application to continental, Deep Sea Drilling Project, and Ocean Drilling Program boreholes. J. Geophys. Res., 95:9305-9325.

Morin, R. H., Newmark, R. L., Barton, C. A., and Anderson, R. N., 1990. State of lithospheric stress and borehole stability at Deep Sea Drilling Project site 504B, eastern equatorial Pacific. J. Geophys. Res., 95:9293-9303.

Newmark, R. L., Zoback, M. D., and Anderson, R. N., 1984. Orientation of in situ stresses in the oceanic crust. Nature, 311:424-428.

Petroy, D. E., and Wiens, D. A., 1989. Historical seismicity and implications for diffuse plate convergence in the northeast Indian Ocean. $J$. Geophys. Res., 94:12301-12319.

Reches, Z., 1987. Determination of the tectonic stress tensor from slip along faults that obey the Coulomb yield condition. Tectonics, 6:849861 .

Richardson, R. M., 1987. Modeling the tectonics of the Indo-Australian plate. Eos, 68:1466. (Abstract)

Shamir, G., and Zoback, M. D., in press. A detailed stress orientation profile in the upper crust near the San Andreas fault at Cajon Pass, California. J. Geophys. Res.

Sibson, R. H., 1974. Frictional constraints on thrust, wrench, and normal faults. Nature, 249:542-544.

Stagg, H.M.J., and Exon, N. F., 1981. The geology of the Scott Plateau and Rowley Terrace, off northwestern Australia. Bur. Miner. Resour. Aust. Bull., 213:1-53.

Stewart, G. S., 1978. Implications for plate tectonics of the August 19, 1977 Indonesian decoupling normal fault earthquake. Eos, 59:326. (Abstract)

Zoback, M. D., and Healy, J. H., 1984. Friction, faulting and in situ stress. Ann. Geophys., 2:689-698.

Zoback, M. D., Moos, D., Mastin, L., and Anderson, R. N., 1985. Well bore breakouts and in situ stress. J. Geophys. Res., 90:5523-5530.

Zoback, M. L., 1989. State of stress and modern deformation of the northern Basin and Range Province. J. Geophys. Res., 94:7710577128.

Zoback, M. L., Zoback, M. D., Adams, J., Assumpêio, M., Bell, S., Bergman, E. A., Blümling, P., Brereton, N. R., Denham, D., Ding, J., Fuchs, K., Gay, N., Gregersen, S., Gupta, H. K., Givishiani, A., Jacob, K., Klein, R., Knoll, P., Magee, M., Mercier, J. L., Müller, B. C., Paquin, C., Rajendran, J., Stephensson, O., Suarez, G., Suter, M., Udas, A., Xu, Z. H., and Zhizhin, M., 1989. Global patterns of intraplate stress: a status report on the world stress map project of the International Lithosphere Program. Nature, 241:291-298.

Date of initial receipt: 3 August 1990

Date of acceptance: 13 June 1991

Ms 123B-134 